\title{
1 Fate of sulfide in the Frasassi cave system and implications for
}

\section{2 sulfuric acid speleogenesis}

4 Daniel S. Jones $^{\mathrm{a}^{*} \dagger}$, Lubos Polerecky ${ }^{\mathrm{b}, \mathrm{c}}$, Sandro Galdenzi ${ }^{\mathrm{d}}$, Brian A. Dempsey ${ }^{\mathrm{e}}$, and Jennifer

5 L. Macalady $\mathbf{a}^{\text {* }}$

6

$7{ }^{a}$ Department of Geosciences, Penn State University, University Park, PA 16802, USA

$8{ }^{b}$ Max Planck Institute for Marine Microbiology, Celsiusstraße 1, D-28359 Bremen, Germany

$9{ }^{c}$ Department of Earth Sciences - Geochemistry, Utrecht University, Budapestlaan 4, 3584 CD,

10 Utrecht, The Netherlands

$11{ }^{d}$ Viale Verdi 10, 60035 Jesi, Italy

$12{ }^{e}$ Department of Civil and Environmental Engineering, Penn State University, University Park, $13 \quad$ PA 16802, USA

14

15 *Correspondence:dsjones@umn.edu,jlm80@psu.edu

$16{ }^{\dagger}$ Current address: Department of Earth Sciences, University of Minnesota, Minneapolis, MN $17 \quad 55455$, USA 


\section{Abstract}

20 The oxidation of hydrogen sulfide $\left(\mathrm{H}_{2} \mathrm{~S}\right)$ has led to the formation of some of the world's largest

21 caves through a process known as sulfuric acid speleogenesis (SAS). Here we present a multi-

22 year study of the large, sulfidic, and actively-forming Frasassi cave system, Italy. We show that

23 despite the presence of abundant sulfide-oxidizing biofilms in Frasassi streams, $\mathrm{H}_{2} \mathrm{~S}(\mathrm{~g})$ degassing

24 to the cave atmosphere was the major sink for dissolved sulfide. Degassing rates ranged from 0.9

25 to $80 \mu \mathrm{mol} \mathrm{m} \mathrm{s}^{-2}$, whereas microbial oxidation rates were between 0.15 and $2.0 \mu \mathrm{mol} \mathrm{m}^{-2} \mathrm{~s}^{-1}$.

26 Furthermore, microsensor measurements showed that sulfuric acid is not a major end product of

27 microbial sulfide oxidation in the streams. Our results suggest that subaerial SAS will be

28 important for karstification, and more important than subaqueous SAS, wherever ground waters

29 with high sulfide concentrations emerge as flowing streams in contact with cave air.

\section{1. Introduction}

Sulfuric acid speleogenesis (SAS) produces porosity in carbonate aquifers where anoxic,

hydrogen-sulfide $\left(\mathrm{H}_{2} \mathrm{~S}\right)$-bearing fluids interact with air-filled voids or oxygenated ground water

to produce sulfuric acid $\left(\mathrm{H}_{2} \mathrm{SO}_{4}\right)$. Ancient karst features formed as a result of SAS include some

of the world's largest and most spectacular caves, such as the massive Lechuguilla Cave and

Carlsbad Caverns in New Mexico (Palmer, 2007) and the exquisitely decorated Kap-Kutan Cave

37 in Turkmenistan (Bottrell et al., 2001). As many as 5\% of explored caves may have had a sulfidic

38 origin (Palmer, 2007), with indications from subsurface drilling that many more are present but

39 inaccessible (Palmer, 1991). In addition to caves, SAS is associated with widespread porosity

40 development in stratified carbonate aquifers and petroleum reservoirs (Hill, 1987; Hill, 1995;

41 Engel and Randall, 2011), with important implications for fluid flow and migration. $\mathrm{CO}_{2}$ release 
42 from sulfuric acid dissolution of carbonates may also have important long-term climate impacts

43 and represent an understudied component of the geological carbon cycle (Torres et al., 2014).

44 The $\mathrm{H}_{2} \mathrm{~S}$ in anoxic carbonate aquifers is most commonly derived from organic-rich

45 sediments or volcanic sources (Egemeier, 1981; Hose et al., 2000; Sarbu, 2000a). Where those

46 ground waters are exposed to oxygen, often at the cave water table, the complete oxidation of

$47 \mathrm{H}_{2} \mathrm{~S}$ to sulfuric acid,

$$
\mathrm{H}_{2} \mathrm{~S}+2 \mathrm{O}_{2} \rightarrow \mathrm{H}_{2} \mathrm{SO}_{4},
$$

can result in extremely rapid carbonate dissolution and aggressive speleogenesis. Depending on where the $\mathrm{H}_{2} \mathrm{~S}$ is oxidized, carbonate dissolution could occur in air-filled areas above the water table (subaerial dissolution) or in the zone below the water table (subaqueous dissolution). table where $\mathrm{H}_{2} \mathrm{~S}(g)$ degasses into the cave atmosphere and oxidizes to sulfuric acid on moist cave walls and ceilings (Principi, 1931; Egemeier, 1981). Where subaerial limestone surfaces are exposed to sulfuric acid, limestone is replaced by a gypsum corrosion residue,

$$
\mathrm{SO}_{4}{ }^{2-}+2 \mathrm{H}^{+}+\mathrm{CaCO}_{3}+\mathrm{H}_{2} \mathrm{O} \rightarrow \mathrm{CaSO}_{4} \cdot 2 \mathrm{H}_{2} \mathrm{O}+\mathrm{CO}_{2} \text {. }
$$

57 Cave enlargement proceeds as gypsum crusts thicken and eventually detach, falling to the cave 58 floor where they can be removed by gypsum-undersaturated ground waters (Egemeier, 1981; Hose et al., 2000) or remain as gypsum floor deposits and 'glaciers' (Davis, 2000; Galdenzi and 60 Maruoka, 2003). However, recent work on SAS has cast doubt on the importance of sulfuric acid corrosion

62 above the water table. $\mathrm{H}_{2} \mathrm{~S}$ oxidation represents a rich source of chemical energy, and sulfidic 63 aquifers with inputs of electron acceptors such as oxygen or nitrate are extensively colonized by 64 chemolithoautotrophic sulfide-oxidizing microorganisms (Hose et al., 2000; Engel et al., 2004; 
65 Macalady et al., 2008). Because microorganisms can oxidize sulfide much faster than abiotic

66 rates alone, they may play an important role in acid production and limestone dissolution in

67 microaerophilic streams where sulfide oxidation is otherwise abiotically limited (Galdenzi et al.,

68 1999; Hose et al., 2000; Engel et al., 2004). Engel et al. (2004) demonstrated that more than 90\%

69 of sulfide disappearance from the stream in Lower Kane Cave, WY, USA, is due to microbial

70 oxidation. Engel et al. (2004) also found evidence that sulfide-oxidizing bacteria enhance

71 limestone dissolution by localizing sulfuric acid production at mineral surfaces, and a later study

72 by Steinhauer et al. (2010) showed that aqueous bioreactors inoculated with sulfidic cave

73 biofilms dissolve limestone up to seven times faster than abiotic control reactors.

74 Observations made in ancient sulfidic caves provide evidence for both subaerial and

75 subaqueous limestone corrosion by SAS. Some studies have argued that, based on morphological

76 evidence, sulfuric acid production below the water table is the main dissolution process for SAS

77 (Davis, 1980; Hill, 1987; Forti et al., 2002). Indeed, the role of subaerial versus subaqueous

78 processes in Carlsbad Cavern currently remains controversial (e.g. Jagnow et al., 2000; Forti et

79 al., 2002; Palmer et al., 2009; Calaforra and De Waele, 2011). However, morphological evidence

80 for subaerial corrosion including cupolas, megascallops, domes, vents, niches, notches, and other

81 features can be found in many sulfidic caves, suggesting that subaerial SAS may be more

82 widespread than generally considered (Audra et al., 2007; Audra et al., 2009; Plan et al., 2012;

83 Temovski et al., 2013). In early work in Frasassi, Galdenzi (1990) proposed a model for cavern

84 development in the Frasassi cave system in which both subaerial and subaqueous processes were

85 important.

86 Thus, the relative importance of subaerial, subaqueous, and microbial processes in SAS

87 remains controversial, perhaps because a quantitative accounting of the mechanisms and rates of 
these processes under differing environmental conditions is lacking. In light of this, we made in situ measurements of $\mathrm{H}_{2} \mathrm{~S}(\mathrm{~g})$ degassing and microbial sulfide oxidation over multiple sites and seasons in the large, actively-forming, and hydrologically dynamic Frasassi cave system (Italy). In Frasassi, morphological and mineralogical observations provide qualitative evidence that significant limestone corrosion has occurred both above and below the water table in the recent past (Galdenzi, 1990). Furthermore, comparable rates of subaerial and subaqueous limestone dissolution are occurring within several meters of the air-water interface (Galdenzi et al., 1997; Mariani et al., 2007). Based on prior observations of pervasive colonization of Frasassi streams and pools by sulfur oxidizing microorganisms (Macalady et al., 2006; Macalady et al., 2008), we hypothesized that biological oxidation below the water table would account for the majority of dissolved $\mathrm{H}_{2} \mathrm{~S}$ disappearance from cave streams. In contrast, here we found that most sulfide lost from streams is released to the cave atmosphere, and that sulfuric acid is not an important end product of microbial sulfide oxidation within submerged biofilms covering rock and sediment surfaces.

\section{The Frasassi Cave System}

(1)

The Grotta Grande del Vento-Grotta del Fiume (Frasassi) cave system (43.4012 N, 12.9656 E) is located in the Mt. Frasassi-Mt. Valmontagnana anticline in the northeastern Appenines, Italy (Fig. 1). The system includes over $25 \mathrm{~km}$ of irregular and ramiform passages in pure platform limestones of the Hettangian Calcare Massiccio Formation (Galdenzi and Maruoka, 2003; Mariani et al., 2007). General characteristics of the hydrology and geochemistry of the cave system have been previously described (Galdenzi et al., 2008; Galdenzi, 2012). 
111 Dissolved sulfide in the Frasassi aquifer is likely derived from bacterial sulfate reduction in

112 organic-rich lenses within underlying evaporites of the Triassic Burano Formation. In the

113 Northeast sector of the active cave level, multiple $\mathrm{H}_{2} \mathrm{~S}$-rich springs emerge at the cave water

114 table and flow into streams and pools accessible by technical caving routes. Total dissolved

115 sulfide $\left(\mathrm{H}_{2} \mathrm{~S}_{\mathrm{T}}\right)$ concentrations in streams and pools vary from below detection $(<2 \mu \mathrm{M})$ to 600

$116 \mu \mathrm{M}$ (Galdenzi et al., 2008; Macalady et al., 2008), whereas dissolved oxygen concentrations in

117 the same waters range from below detection $(<2 \mu \mathrm{M})$ to $30 \mu \mathrm{M}$ (Macalady et al., 2008). Nitrate

118 concentrations are perennially undetectable $(<0.1 \mu \mathrm{M})$ (Macalady et al., 2008). Sulfidic cave

119 waters are slightly saline (conductivity $1.5-3.5 \mathrm{mS} / \mathrm{cm}$ ), and consistently between $13-14^{\circ} \mathrm{C}$ year

120 round. Within 1 meter of the water table, $\mathrm{H}_{2} \mathrm{~S}(\mathrm{~g})$ concentrations in the cave air range from $<0.2$

121 to 25 parts-per-million by volume (ppmv), and are typically less than 10 ppmv (Macalady et al., 122 2007).

123

124

125 3. Methods

126

127 3.1 Field sampling and chemical analyses

128 Concentrations of $\mathrm{H}_{2} \mathrm{~S}_{\mathrm{T}}$ (total dissolved sulfide) and $\mathrm{O}_{2}$ in cave streams were measured

129 with a portable spectrophotometer (Hach, Loveland, CO) using methylene blue (Hach method 130 690) and indigo carmine (Hach method 8316) methods, respectively. Replicate $\mathrm{H}_{2} \mathrm{~S}_{\mathrm{T}}$ analyses

131 were within $3 \%$ of each other, and replicate $\mathrm{O}_{2}$ analyses were within $25 \%$ of each other. Water

132 temperature, $\mathrm{pH}$ and conductivity were measured using a 350i multimeter and handheld probes

133 (WTW, Weiheim, Germany). Water samples for laboratory analyses were filtered immediately in 
134 the field $(0.2 \mu \mathrm{m})$ into acid-washed containers. Samples for dissolved calcium and other cations

135 were preserved with concentrated nitric acid and measured by inductively coupled plasma atomic

136 emission spectroscopy (ICP-AES) at the Penn State Materials Characterization Laboratory.

137 Dissolved inorganic carbon (DIC) was determined by headspace $\mathrm{CO}_{2}(g)$ measurements using the 138 method of Dawson et al. (2013).

139 Surface flow velocity was determined using floating indicators. Discharge was calculated

140 by multiplying surface flow velocity with the stream cross sectional area and a factor of 0.85 ,

141 which corrects for differences between surface and depth-averaged subsurface flow velocities

142 (Gallagher and Stevenson, 1999).

143

$144 \quad 3.2 \mathrm{H}_{2} \mathrm{~S}$ degassing rate

145 The rate of $\mathrm{H}_{2} \mathrm{~S}(\mathrm{~g})$ degassing was measured using a portable flux chamber connected to a

146 handheld gas detector (MX2100, ENMET corp., USA) (Fig. A.1). Similar flux chamber

147 approaches have been widely applied for measuring air-water gas exchange (Frankignoulle,

148 1988; Kremer et al., 2003; Borges et al., 2004). The flux chamber was connected to the detector

149 by a BX2100 air pump (ENMET Corp., USA), and the degassing flux was calculated from the

150 rate of increase of $\mathrm{H}_{2} \mathrm{~S}(\mathrm{~g})$ in the chamber, after correcting for air removed by the pump and for

151 detector response time (Appendix A.1, Fig. A.1 and A.2). To compensate for uncertainty

152 introduced by the flux-chamber system, between 2-5 measurements were performed at each

153 sampling location. Complete details on $\mathrm{H}_{2} \mathrm{~S}(g)$ degassing measurements are provided in the 154 supplementary methods (Appendix A.1).

155

1563.3 In situ microsensor analyses 
to a custom-designed portable microsensing apparatus (Weber et al., 2007). Vertical sediments and rocks, and $\mathrm{H}_{2} \mathrm{~S}_{\mathrm{T}}$ flux was determined from the $\mathrm{H}_{2} \mathrm{~S}_{\mathrm{T}}$ gradient using Fick's first law

161 of diffusion. previously described. Clark-type $\mathrm{O}_{2}$ electrodes (Revsbech, 1989) were calibrated by a linear twopoint calibration in oxygen-saturated water and anoxic sediment. $\mathrm{H}_{2} \mathrm{~S}$ electrodes (Kühl et al., 1998) were calibrated by linear two-point calibration in sulfidic stream water and a $\mathrm{Na}_{2} \mathrm{~S}$ standard. $\mathrm{H}_{2} \mathrm{~S}_{\mathrm{T}}$ values were calculated from microsensor-derived $\mathrm{H}_{2} \mathrm{~S}(a q)$ concentrations and $\mathrm{pH}$

167 values using equation $\mathrm{H}_{2} \mathrm{~S}_{\mathrm{T}}=\mathrm{H}_{2} \mathrm{~S}(a q) \times\left[1+K_{1} / \mathrm{H}_{3} \mathrm{O}^{+}\right]$, with the $K_{1}$ value corrected for temperature and salinity according to Millero et al. (1988). pH electrodes (de Beer et al., 2006) were calibrated using buffer solutions of $\mathrm{pH} 4.01$ and $\mathrm{pH} 7.00$ (Mettler-Toledo, Giessen, Germany). successful measurements in sulfidic springs outside the cave, we had no success with $\mathrm{H}_{2} \mathrm{~S}$ sensors and limited success with oxygen sensors inside the cave. The following year we returned

174 with the Caver Operated Microsensor System (COMS; Fig. A.3c), which is a smaller and more

175 robust version of the motorized Diver Operated Microsensor System (DOMS) described by

176 Weber et al. (2007). By packing the sensor contacts with hygroscopic beads and sealing all

177 contacts as completely as possible prior to entering the cave, the COMS electronics were

178 protected from moisture and $\mathrm{H}_{2} \mathrm{~S}(g)$ vapors in the cave air, which resulted in a substantially 179 improved stability of the signal. 
181

182 measured $\mathrm{H}_{2} \mathrm{~S}_{\mathrm{T}}$ gradients according to the Fick's first law of diffusion, assuming steady state,

183

where $D$ is the diffusion coefficient of $\mathrm{H}_{2} \mathrm{~S}(a q)$ corrected for in situ temperature according to 184

Jørgensen and Revsbech (1983). Fluxes measured at each site were averaged from three separate microsensor profiles collected within $1 \mathrm{~cm}^{2}$ of investigated biofilm.

$$
J_{\text {mich } 2 S}=D \frac{d C_{H 2 S T}}{d z},
$$

\subsection{Stream model}

A 1-dimensional reaction-transport model was used to relate the loss of $\mathrm{H}_{2} \mathrm{~S}_{\mathrm{T}}$ to chemical changes in the bulk stream water. The processes affecting the $\mathrm{H}_{2} \mathrm{~S}_{\mathrm{T}}$ loss included (1) $\mathrm{H}_{2} \mathrm{~S}(g)$ degassing from the stream surface to the cave atmosphere, (2) microbial sulfide oxidation in stream biofilms, and (3) abiotic sulfide oxidation, all of which were constrained by the field measurements. Assuming steady state approximation, changes in $\mathrm{H}_{2} \mathrm{~S}_{\mathrm{T}}$ concentration (denoted $C_{s}$, mol $\left.\mathrm{m}^{-3}\right)$ along the stream $(x, \mathrm{~m})$ are given by

$$
\frac{C_{s}}{x} v=J_{g a s} \frac{1}{h} \quad J_{m i c} \frac{1}{h} R_{\text {abio }},
$$

where $v$ is stream flow velocity $\left(\mathrm{m} \mathrm{s}^{-1}\right)$ and $h$ is depth $(\mathrm{m})$. The $\mathrm{H}_{2} \mathrm{~S}(g)$ degassing flux, $J_{\text {gas }}(\mathrm{mol}$

$196 \mathrm{~m}^{-2} \mathrm{~s}^{-1}$ ) was dependent on stream flow velocity and followed an empirical relationship derived

197 from field measurements (Fig. 2). The $\mathrm{H}_{2} \mathrm{~S}_{\mathrm{T}}$ removal flux due to microbial oxidation, $J_{\text {mic }}$ (mol

$198 \mathrm{~m}^{-2} \mathrm{~s}^{-1}$ ), was assumed to span the range determined by microsensors across all measured sites.

199 The rate of abiotic chemical oxidation, $R_{\text {abio }}\left(\mathrm{mol} \mathrm{m}^{-3} \mathrm{~s}^{-1}\right)$, was calculated based on

200 concentrations of dissolved $\mathrm{H}_{2} \mathrm{~S}_{\mathrm{T}}$ and $\mathrm{O}_{2}$ using kinetic equations from Millero et al. (1987). Rates

201 for air-water exchange of $\mathrm{CO}_{2}$ were calculated using theoretical volatilization equations 
202 (Schwarzenbach et al., 1993) using measured $\mathrm{CO}_{2}(a q)$ values and the assumption that mass 203 transfer coefficients for $\mathrm{CO}_{2}(a q)$ and $\mathrm{H}_{2} \mathrm{~S}(a q)$ were proportional. Downstream changes in $\mathrm{pH}$ 204 were calculated based on $\mathrm{H}_{2} \mathrm{~S}(g)$ and $\mathrm{CO}_{2}(g)$ degassing, using the reaction block in PHREEQC

205 (Parkhurst et al., 1999) to incrementally remove $\mathrm{H}_{2} \mathrm{~S}(a q)$ and $\mathrm{CO}_{2}(a q)$ from the stream water. 206 Complete model derivation and input parameters are provided in the supplementary materials 207 (Appendix A.2).

208

\section{Results}

Gas flux chamber measurements of areal rates of $\mathrm{H}_{2} \mathrm{~S}(\mathrm{~g})$ degassing in Frasassi streams

211 varied by two orders of magnitude, from 0.9 to $80 \mu \mathrm{mol} \mathrm{m} \mathrm{m}^{-1}$ (Table 1). The large range in rates

212 was mainly due to variation in stream flow velocity and bulk $\mathrm{H}_{2} \mathrm{~S}_{\mathrm{T}}$ concentration (Fig. 2). In

213 "type 1 sulfidic" cave waters (Fig. 2a), the degassing rates increased approximately linearly with 214 the surface flow velocity with a slope of $218 \mu \mathrm{mol} \mathrm{m}^{-3}\left(\mathrm{r}^{2}=0.89, \mathrm{p}<0.001\right)$. A similar linear 215 correlation was found for "type 2 sulfidic" waters, but with a lower slope $\left(23.7 \mu \mathrm{mol} \mathrm{m}{ }^{-3}\right.$, $\left.216 \mathrm{r}^{2}=0.59, \mathrm{p}<0.001\right)$.

217 Conspicuous white biofilms at the sediment-water interface or attached to submerged

218 limestone surfaces were observed for all sampling events. In these biofilms, $\mathrm{O}_{2}$ and $\mathrm{H}_{2} \mathrm{~S}_{\mathrm{T}}$

219 concentrations exhibited steep gradients, confirming the role of microbial sulfide oxidation as a

220 sink for sulfide (Fig. 3 and Fig. A.4). Microbial sulfide oxidation rates calculated from

221 microsensor profiles ranged from 0.08 to $2.0 \mu \mathrm{mol} \mathrm{m}^{-2} \mathrm{~s}^{-1}$ (Table 1). $\mathrm{pH}$ did not change

222 significantly across biofilm-water interfaces or within the biofilms. However, $\mathrm{pH}$ did decrease in 223 organic-rich, anoxic sediments below the biofilms (Fig. 3). 
At a site where a spring-fed sulfidic stream flowed without additional ground water

225

226

227

228

229

230

231

232

233

234

235

236

237

238

239

240

241

242

243

\section{4}

245

246 inputs or outputs (site PC; Fig. 1, Fig. A.3), bulk water concentrations of $\mathrm{H}_{2} \mathrm{~S}_{\mathrm{T}}$ decreased while $\mathrm{O}_{2}$ and $\mathrm{pH}$ increased downstream from the emergence (Fig. 4, symbols, and Fig. A.5). There was no measurable change in dissolved $\mathrm{Ca}^{2+}$ (Tables A.1 and A.2). The measured $\mathrm{H}_{2} \mathrm{~S}_{\mathrm{T}}$ and $\mathrm{pH}$ gradients were in good agreement with those predicted by the reaction-transport model (Fig. 4, solid lines). This confirmed that degassing was the major driver of $\mathrm{H}_{2} \mathrm{~S}_{\mathrm{T}}$ loss (contributing on average $88 \%$ to $98 \%$ ) and $\mathrm{pH}$ increase in the bulk stream water. Benthic microbial sulfide oxidation was only minor (on average $2 \%$ to $12 \%$ ), and abiotic oxidation in the bulk water was negligible $(<0.03 \%$; Table A.3). Due to the fragility of the microsensor apparatus, we were not able to obtain microsensor profiles from all sites (Table 1). However, we were able to use rates measured in the cave to constrain the model.

After successful validation of the model at site PC, we applied it to other sites (GB, RS, GS) where stream flow is more complex. At these type 2 sulfidic water sites (Fig. $2 a), \mathrm{H}_{2} \mathrm{~S}(g)$ degassing fluxes were generally lower than at site PC (Fig. 2b), although still larger than microbial oxidation rates (Table 1). Model predictions suggested that, similar to site PC, degassing was the major driver of $\mathrm{H}_{2} \mathrm{~S}_{\mathrm{T}}$ loss (contributing on average $75 \%$ to $86 \%$ of total $\mathrm{H}_{2} \mathrm{~S}_{\mathrm{T}}$ depletion), whereas microbial sulfide oxidation was less important (on average $14 \%$ to $25 \%$;

Table A.4). Because these sites were influenced by non-quantified ground water inputs, model predictions could not be reliably compared with field data.

\section{Discussion}

\subsection{Fate of $\mathrm{H}_{2} \mathrm{~S}$ in Frasassi streams}



rates (e.g. Jørgensen et al., 1979; Jannasch et al., 1991; Jensen et al., 2009; Luther et al., 2011), sulfide removal by microbial oxidation is much faster in Frasassi streams than abiotic oxidation profiles from all sites. However, our measured rates nonetheless provide an appropriate constraint for the model. Both in situ measurements and transport modeling show that $\mathrm{H}_{2} \mathrm{~S}(g)$ degassing rates are at least an order of magnitude higher than microbial sulfide oxidation (Table 1). Additionally, degassing explains the downstream increase in $\mathrm{pH}$ observed at site PC (Fig. 4).

Therefore we can be confident in the conclusion that most of the sulfide lost from Frasassi streams is released to the cave atmosphere. Our results directly challenge the notion that microbial sulfide oxidation below the water table is generally the primary driver in SAS, as some 261 previous studies have suggested (Davis, 1980; Engel et al., 2004).

\subsection{Role of biological sulfide oxidation}

Although biological oxidation accounts for some of the sulfide disappearance from

265 Frasassi streams, $\mathrm{pH}$ microsensor profiles show that the biofilms do not produce significant 266 amounts of sulfuric acid (Fig. 3). Therefore, the majority of the sulfide is likely oxidized to 267 intermediate sulfur species such as zero-valent sulfur,

$$
2 \mathrm{H}_{2} \mathrm{~S}+\mathrm{O}_{2} \rightarrow 2 \mathrm{~S}^{\mathrm{o}}+2 \mathrm{H}_{2} \mathrm{O} \text {. }
$$


269 In contrast, $\mathrm{pH}$ decreases are regularly observed in biofilms from other environments where

270 sulfide is completely oxidized to sulfuric acid (e.g. Jørgensen and Revsbech, 1983; Schwedt et

271 al., 2011). Consistent with this interpretation, abundant intracellular and/or extracellular $S^{\circ}$

272 particles are perennially observed in Frasassi biofilms and sediments, regardless of their

273 taxonomic composition or the surrounding water chemistry (Macalady et al., 2006; Macalady et

274 al., 2008), which give the stream biofilms their conspicuous white color (Fig. A.3). Incomplete

275 sulfide oxidation thus supports a thriving chemosynthetic ecosystem in the streams, but does not

276 contribute directly to acid production.

277 Decreases in $\mathrm{pH}$ and increases in $\mathrm{H}_{2} \mathrm{~S}_{\mathrm{T}}$ concentration were, however, observed in the

278 anoxic sediments immediately below the zone of sulfide oxidation, indicating that sulfur and/or

279 carbon recycling produces acid (Fig. 3). Furthermore, a single pH profile obtained by a

280 microsensor that broke when it accidentally hit hard rock indicated that the $\mathrm{pH}$ remained low in

281 deeper sediments down to the sediment-rock interface (Fig. 3b). The observed $\mathrm{pH}$ decrease in the

282 sediments could be due to organic acid and $\mathrm{CO}_{2}$ production via fermentation, sulfate reduction in

283 the absence of metal sulfide precipitation (Ben-Yaakov, 1973; Boudreau and Canfield, 1988;

284 Meister, 2013), and/or disproportionation of $S^{\circ}$ (Finster et al., 1998). Although sulfur-oxidizing

285 autotrophs in the biofilms supply organic matter for fermentation and sulfate reduction and $\mathrm{S}^{\circ}$ for

286 sulfur disproportionation (Macalady et al., 2008), it appears that sulfide oxidation and acid

287 production are only weakly coupled.

288

2895.3 Implications for speleogenesis in the Frasassi cave system

290 Most of the $\mathrm{H}_{2} \mathrm{~S}(\mathrm{~g})$ that degasses from cave streams is thought to oxidize to sulfuric acid

291 on moist wall surfaces in the oxygen-rich cave atmosphere. Near flowing sulfidic streams, cave 
292 walls and ceilings are covered with acidic $(\mathrm{pH}<4)$ gypsum corrosion residues often $>10 \mathrm{~cm}$

293 thick, and the gypsum surface is colonized by extremophilic sulfur-oxidizers that produce highly

294 acidic (pH 0-2) subaerial biofilms (Macalady et al., 2007). In some locations, small yellow

295 elemental sulfur rosettes are associated with wall and biofilm surfaces (Macalady et al., 2007;

296 Jones et al., 2012). Further from flowing streams, gypsum crusts thin and eventually give way to

297 exposed limestone and mildly acidic (pH 6) wall communities (Jones et al., 2008). In addition to

298 biological sulfide oxidation by these wall microbial communities, abiotic sulfide oxidation may

299 also be important above the water table.

300 Widespread evidence for aggressive subaerial corrosion has been documented in multiple

301 cave levels that lie above the currently active level, including cave passage geometries, cupolas

302 and other corrosion features above vertical phreatic conduits, and extensive microcrystalline

303 gypsum deposits with light $\mathrm{S}$ isotopic signatures (Galdenzi, 1990; Galdenzi and Maruoka, 2003;

304 Galdenzi, 2012). These features indicate that conditions favorable for strong $\mathrm{H}_{2} \mathrm{~S}(\mathrm{~g})$ degassing

305 have existed over long periods, at least in the last phases of the 2-3 million year history of cave

306 development in the Frasassi system (Taddeucci et al., 1992; Galdenzi and Maruoka, 2003).

307 In multi-year limestone tablet dissolution experiments conducted at sample site RS

308 (Galdenzi et al., 1997), average mass loss was similar for tablets incubated above and below the

309 stream surface (Fig. 5; see also Galdenzi, 2012). Methods for this experiment are provided here

310 in the supplementary content (Appendix A.3). Since microbial sulfide consumption in Frasassi

311 streams does not appear to result in significant sulfuric acid production, these results imply that

312 other processes in the stream water may also be important for speleogenesis. Notably, rapid

313 carbonate dissolution also occurs at Frasassi below stable haloclines in stratified lakes where

314 oxygen is below detection limits (Mariani et al., 2007). 
5.4 Implications for sulfuric acid speleogenesis

Our results suggest that apparently conflicting views on subaerial versus subaquous SAS near the water table can be reconciled using a conceptual model that takes $\mathrm{H}_{2} \mathrm{~S}_{\mathrm{T}}$ concentrations and water flow characteristics into account (Fig. 6). Near flowing waters in Frasassi, degassing predominates due to high $\mathrm{H}_{2} \mathrm{~S}_{\mathrm{T}}$ concentration and rapid stream flow. In contrast, streams in Lower Kane Cave, WY, USA, have rapid flow but much lower $\mathrm{H}_{2} \mathrm{~S}_{\mathrm{T}}$ concentrations, and microbial oxidation is therefore faster than degassing (Engel et al., 2004). Consistent with our conceptual model, Engel et al. (2004) report $\mathrm{H}_{2} \mathrm{~S}(g)$ degassing fluxes between 0.35-1.3 $\mu \mathrm{mol} \mathrm{m}{ }^{-2}$

$324 \mathrm{~s}^{-1}$ for the Lower Kane Cave stream, which are slower than $\mathrm{H}_{2} \mathrm{~S}(g)$ degassing fluxes at most 325 Frasassi locations but within the range of microbial oxidation fluxes measured here (Table 1). Near sulfidic Frasassi lakes such as Lago Verde and Lago Claudia, there is no detectable $\mathrm{H}_{2} \mathrm{~S}(g)$ in the cave air and little to no subaerial gypsum deposition above the water table due to very slow water flow. Similarly, Movile Cave (Romania) has high dissolved sulfide but low cave 329 air $\mathrm{H}_{2} \mathrm{~S}(g)$, slow gypsum precipitation, and scarce subaerial corrosion features (Sarbu, 2000b; 330 Galdenzi, 2001), consistent with its largely stagnant water table. Rapid $\mathrm{H}_{2} \mathrm{~S}(g)$ degassing and 331 subaerial corrosion are expected for most locations within Cueva de Villa Luz, Mexico, due to 332 high $\mathrm{H}_{2} \mathrm{~S}_{\mathrm{T}}$ and turbulent water flow (Hose et al., 2000), as well as near the highly sulfidic and 333 turbulent cave streams in Grotta Nuova di Rio Garrafo near Acquasanta Terme, Italy (Galdenzi et 334 al., 2010; Jones et al., 2010). Water temperature and thermal air flow may also impact $\mathrm{H}_{2} \mathrm{~S}(\mathrm{~g})$ 335 dynamics in these and other caves (Galdenzi, 2001; Audra et al., 2007; Audra et al., 2009), and 336 future research will continue to explore how $\mathrm{H}_{2} \mathrm{~S}_{\mathrm{T}}$ concentration, stream flow characteristics, and 
337 other factors impact subaerial sulfuric acid speleogenesis and the evolution of sulfidic karst 338 systems.

339 We were surprised to find that the presence of a conspicuous sulfide-oxidizing microbiota

340 is not a reliable indicator for subaqueous SAS. However, we also note that microbial recycling of

341 chemoautotrophic biofilms produces acidity that may contribute to limestone dissolution even

342 under conditions where sulfuric acid is not directly produced by chemosynthesis. Microbially-

343 driven speleogenesis may therefore occur in a broader range of carbonate-hosted subsurface

344 ecosystems, powered by chemosynthetically-derived organic carbon.

\section{Acknowledgements}

347 This work was funded by grants from the National Science Foundation (NSF EAR-0525503),

348 NASA Astrobiology Institute (PSARC, NNA04CC06A) (J.L.M.), and the Max-Planck Society

349 (L.P.). We thank A. Montanari for logistical support and the use of facilities and laboratory space

350 at the Osservatorio Geologico di Coldigioco (Italy), S. Hausler and J. Klatt for help with

351 microsensor measurements, S. Dattagupta and B. McCauley for field assistance, B. Thomas and

352 S. Dattagupta for advice on analytical methods, and L. Hose, L. Rosales-Lagarde, M. Fantle, and

353 D. de Beer for insightful discussions. D.S.J. and J.L.M. thank S. Mariani, S. Cerioni, M.

354 Mainiero, F. Baldoni, S. Carnevali and members of the Gruppo Speleologico C.A.I. di Fabriano 355 and Ancona for assistance during field campaigns. 
Audra, P., Hobléa, F., Bigot, J.-Y., Nobecourt, J.-C., 2007. The role of condensation-corrosion in thermal speleogenesis: study of a hypogenic sulfidic cave in Aix-les-Bains, France. Acta Carsologica 36, 185-194.

Audra, P., Mocochain, L., Bigot, J., Nobecourt, J., 2009. Morphological indicators of speleogenesis: hypogenic speleogens. Hypogene speleogenesis and karst hydrogeology of artesian basins. Ukrainian Institute of Speleology and Karstology, Special Paper 1, 23-32.

Ben-Yaakov, S., 1973. pH buffering of pore water of recent anoxic marine sediments. Limnol. Oceanogr. 18, 86-94.

Borges, A.V., Delille, B., Schiettecatte, L.S., Gazeau, F., Abril, G., Frankignoulle, M., 2004. Gas transfer velocities of $\mathrm{CO}_{2}$ in three European estuaries (Randers Fjord, Scheldt, and Thames). Limnol. Oceanogr. 49, 1630-1641.

Bottrell, S., Crowley, S., Self, C., 2001. Invasion of a karst aquifer by hydrothermal fluids: evidence from stable isotopic compositions of cave mineralization. Geofluids 1, 103-121.

Boudreau, B.P., Canfield, D.E., 1988. A provisional diagenetic model for $\mathrm{pH}$ in anoxic porewaters: Application to the FOAM site. J. Mar. Res. 46, 429-455.

Calaforra, J.-M., De Waele, J., 2011. New peculiar cave ceiling forms from Carlsbad Caverns (New Mexico, USA): the zenithal ceiling tube-holes. Geomorphology 134, 43-48.

Davis, D.G., 1980. Cavern development in the Guadalupe Mountains: A critical review of recent hypotheses. NSS Bull. 42, 42-48.

Davis, D.G., 2000. Extraordinary features of Lechuguilla Cave, Guadalupe Mountains, New Mexico. J. Cave Karst Stud. 62, 147-157.

Dawson, K.S., Schaperdoth, I., Freeman, K.H., Macalady, J.L., 2013. Anaerobic biodegradation of the isoprenoid biomarkers pristane and phytane. Org. Geochem. 65, 118-126.

de Beer, D., Sauter, E., Niemann, H., Kaul, N., Foucher, J.P., Witte, U., Schlüter, M., Boetius, A., 2006. In situ fluxes and zonation of microbial activity in surface sediments of the Håkon Mosby Mud Volcano. Limnol. Oceanogr. 51, 1315-1331.

Egemeier, S.J., 1981. Cavern development by thermal water. NSS Bull. 43, 31-51.

Engel, A.S., Randall, K.W., 2011. Experimental evidence for microbially mediated carbonate dissolution from the saline water zone of the Edwards Aquifer, central Texas. Geomicrobiol. J. 28, 313-327.

Engel, A.S., Stern, L.A., Bennett, P.C., 2004. Microbial contributions to cave formation: New insights into sulfuric acid speleogenesis. Geology 32, 369-372.

Finster, K., Liesack, W., Thamdrup, B., 1998. Elemental sulfur and thiosulfate disproportionation by Desulfocapsa sulfoexigens sp. nov., a new anaerobic bacterium isolated from marine surface sediment. Appl. Environ. Microbiol. 64, 119-125.

Forti, P., Galdenzi, S., Sarbu, S.M., 2002. Hypogenic caves: a powerful tool for the study of seeps and their environmental effects. Cont. Shelf Res. 22, 2373.

Frankignoulle, M., 1988. Field measurements of air-sea $\mathrm{CO}_{2}$ exchange. Limnol. Oceanogr., 313322.

Galdenzi, S., 1990. Un modello genetico per la Grotta Grande del Vento. In: Galdenzi, S., Menichetti, M. (Eds.), Il carsismo della Gola di Frasassi: Memorie Istituto Italiano di Speologia, pp. 123-142.

Galdenzi, S., 2001. L'Azione morphogenetica delle acque sulfuree nelle Grotte di Frasassi, Acquasanta Terme (Appennino Marchigiano - Italia) e di Movile (Dobrogea - Romania). Le Grotte d'Italia 2, 49-61. 
404

405

406

407

408

409

410

411

412

413

414

415

416

417

418

419

420

421

422

423

424

425

426

427

428

429

430

431

432

433

434

435

436

437

438

439

440

441

442

443

444

445

446

447

Galdenzi, S., 2012. Corrosion of limestone tablets in sulfidic ground-water: measurements and speleogenetic implications. Int. J. Speleol. 41, 3.

Galdenzi, S., Cocchioni, F., Fillipponi, G., Morichetti, L., Scuri, S., Selvaggio, R., Cocchioni, M., 2010. The sulfidic thermal caves of Acquasanta Terme (central Italy). J. Cave Karst Stud. 72, 43-58.

Galdenzi, S., Cocchioni, M., Morichetti, L., Amici, V., Scuri, S., 2008. Sulfidic ground-water chemistry in the Frasassi caves, Italy. J. Cave Karst Stud. 70, 94-107.

Galdenzi, S., Maruoka, T., 2003. Gypsum deposits in the Frasassi Caves, central Italy. J. Cave Karst Stud. 65, 111-125.

Galdenzi, S., Menichetti, M., Forti, P., 1997. La corrosione di placchette calcaree ad opera di acque sulfuree: dait sperimentali in ambiente ipogeo. Proceedings of the 12th International Congress of Speleology, La Chaux-de-Fonds, Switzerland 1, 187-190.

Galdenzi, S., Menichetti, M., Sarbu, S., Rossi, A., 1999. Frasassi caves: a biogenic hypogean karst system, Proceedings European Conference Karst, pp. 101-106.

Gallagher, A.S., Stevenson, N.J., 1999. Streamflow. In: Bain, M.B., Stevenson, N.J. (Eds.), Aquatic Habitat Assessment: common methods. American Fisheries Society, Bethesda, MD, pp. 149-157.

Hill, C., 1987. Geology of Carlsbad cavern and other caves in the Guadalupe Mountains, New Mexico and Texas, New Mexico Bureau of Mines and Mineral Resources, Bulletin 117, pp. 150.

Hill, C.A., 1995. Sulfur redox reactions: hydrocarbons, native sulfur, Mississippi Valley-type deposits, and sulfuric acid karst in the Delaware Basin, New Mexico and Texas. Environ. Geol. 25, 16-23.

Hose, L.D., Palmer, A.N., Palmer, M.V., Northup, D.E., Boston, P.J., DuChene, H.R., 2000. Microbiology and geochemistry in a hydrogen-sulfide-rich karst environment. Chem. Geol. 169, 399-423.

Jagnow, D.H., Hill, C.A., Davis, D.G., DuChene, H.R., Cunningham, K.I., Northup, D.E., Queen, J.M., 2000. History of the sulfuric acid theory of speleogenesis in the Guadalupe Mountains, New Mexico. J. Cave Karst Stud. 62, 54-59.

Jannasch, H., Wirsen, C., Molyneaux, S., 1991. Chemoautotrophic sulfur-oxidizing bacteria from the Black Sea. Deep Sea Research Part A. Oceanographic Research Papers 38, S1105S1120.

Jensen, H.S., Nielsen, A.H., Hvitved-Jacobsen, T., Vollertsen, J., 2009. Modeling of hydrogen sulfide oxidation in concrete corrosion products from sewer pipes. Water Environ. Res. 81, 365-373.

Jones, D., Tobler, D., Schaperdoth, I., Mainiero, M., Macalady, J., 2010. Community structure of subsurface biofilms in the thermal sulfidic caves of Acquasanta Terme, Italy. Appl. Environ. Microbiol. 76, 5902-5910.

Jones, D.S., Lyon, E.H., Macalady, J.L., 2008. Geomicrobiology of biovermiculations from the Frasassi cave system, Italy. J. Cave Karst Stud. 70, 78-93.

Jørgensen, B.B., Kuenen, J.G., Cohen, Y., 1979. Microbial transformations of sulfur compounds in a stratified lake (Solar Lake, Sinai). Limnol. Oceanogr., 799-822.

Jørgensen, B.B., Revsbech, N.P., 1983. Colorless sulfur bacteria, Beggiatoa spp. and Thiovulum spp., in $\mathrm{O}_{2}$ and $\mathrm{H}_{2} \mathrm{~S}$ microgradients. Appl. Environ. Microbiol. 45, 1261-1270. 
Kremer, J.N., Nixon, S.W., Buckley, B., Roques, P., 2003. Technical note: Conditions for using the floating chamber method to estimate air-water gas exchange. Estuar. Coasts 26, $985-$ 990.

Kühl, M., Steuckart, C., Eickert, G., Jeroschewski, P., 1998. A $\mathrm{H}_{2} \mathrm{~S}$ microsensor for profiling biofilms and sediments: application in an acidic lake sediment. Aquat. Microb. Ecol. 15, 201-209.

Luther, G., Findlay, A.J., MacDonald, D.J., Owings, S.M., Hanson, T.E., Beinart, R.A., Girguis, P.R., 2011. Thermodynamics and Kinetics of sulfide oxidation by oxygen: a look at inorganically controlled reactions and biologically mediated processes in the environment. Front. Microbiol. 62, 1-9.

Macalady, J.L., Dattagupta, S., Schaperdoth, I., Jones, D.S., Druschel, G.K., Eastman, D., 2008. Niche differentiation among sulfur-oxidizing bacterial populations in cave waters. ISME J. 2, 509-601.

Macalady, J.L., Jones, D.S., Lyon, E.H., 2007. Extremely acidic, pendulous microbial biofilms from the Frasassi cave system, Italy. Environ. Microbiol. 9, 1402-1414.

Macalady, J.L., Lyon, E.H., Koffman, B., Albertson, L.K., Meyer, K., Galdenzi, S., Mariani, S., 2006. Dominant microbial populations in limestone-corroding stream biofilms, Frasassi cave system, Italy. Appl. Environ. Microbiol. 72, 5596-5609.

Mariani, S., Mainiero, M., Barchi, M., Van Der Borg, K., Vonhof, H., Montanari, A., 2007. Use of speleologic data to evaluate Holocene uplifting and tilting: An example from the Frasassi anticline (northeastern Apennines, Italy). Earth Planet. Sci. Lett. 257, 313-328.

Meister, P., 2013. Two opposing effects of sulfate reduction on carbonate precipitation in normal marine, hypersaline, and alkaline environments. Geology 41, 499-502.

Millero, F.J., Hubinger, S., Fernandez, M., Garnett, S., 1987. Oxidation of H2S in seawater as a function of temperature, $\mathrm{pH}$, and ionic strength. Environ. Sci. Technol. 21, 439-443.

Millero, F.J., Plese, T., Fernandez, M., 1988. The dissociation of hydrogen sulfide in seawater. Limnol. Oceanogr., 269-274.

Palmer, A.N., 1991. Origin and morphology of limestone caves. Geol. Soc. Am. Bull. 103, 1-21. Palmer, A.N., 2007. Cave Geology. Cave Books, Dayton, OH.

Palmer, A.N., Palmer, M.V., Queen, J.M., DuChene, H.R., Cunningham, K.I., 2009. The Guadalupe Mountains, New Mexico - Texas. In: Palmer, A.N., Palmer, M.V. (Eds.), Caves and Karst of the USA. National Speleological Society, Inc., Huntsville, Alabama, pp. 446.

Parkhurst, D.L., Appelo, C., Survey, G., 1999. User's guide to PHREEQC (Version 2): A computer program for speciation, batch-reaction, one-dimensional transport, and inverse geochemical calculations. US Geological Survey Water-Resources Investigations Report 99-4259, 312.

Plan, L., Tschegg, C., De Waele, J., Spötl, C., 2012. Corrosion morphology and cave wall alteration in an Alpine sulfuric acid cave (Kraushöhle, Austria). Geomorphology 169, 4554.

Principi, P., 1931. Fenomeni di idrologia sotterranea nei dintouni di Triponzo (Umbria). Le Grotte d'Italia 5, 1-4.

Revsbech, N.P., 1989. An oxygen microsensor with a guard cathode. Limnol. Oceanogr. 34, 474478.

Sarbu, S.M., 2000a. Movile Cave: A chemoautotrophically based groundwater ecosystem. Ecosystems of the world, 319-344. 
Sarbu, S.M., 2000b. Movile Cave: A chemoautotrophically based groundwater ecosystem. In: Wilkens, H., Culver, D.C., Humphreys, W.F. (Eds.), Ecosystems of the World. Elsevier, Amsterdam, pp. 319-344.

Schwarzenbach, R.P., Gschwend, P.M., Imboden, D.M., 1993. Environmental Organic Chemistry. John Wiley and Sons, Inc., New York, NY.

Schwedt, A., Kreutzmann, A.-C., Polerecky, L., Schulz-Vogt, H.N., 2011. Sulfur respiration in a marine chemolithoautotrophic Beggiatoa strain. Front. Microbiol. 2.

Steinhauer, E.S., Omelon, C.R., Bennett, P.C., 2010. Limestone corrosion by neutrophilic sulfuroxidizing bacteria: a coupled microbe-mineral system. Geomicrobiol. J 27, 723-738.

Taddeucci, A., Tuccimei, P., Voltaggio, M., 1992. Studio geocronologico del complesso carsico Grotta del Fiume-Grotta Grande del Vento (Gola di Frasassi, AN) e indicazioni paleoambientali. Il Quaternario 5, 213-222.

Temovski, M., Audra, P., Mihevc, A., Spangenberg, J.E., Polyak, V., McIntosh, W., Bigot, J.-Y., 2013. Hypogenic origin of Provalata Cave, Republic of Macedonia: a distinct case of successive thermal carbonic and sulfuric acid speleogenesis. Int. J. Speleol. 42, 7.

Torres, M.A., West, A.J., Li, G., 2014. Sulphide oxidation and carbonate dissolution as a source of $\mathrm{CO}_{2}$ over geological timescales. Nature 507, 346-349.

Weber, M., Faerber, P., Meyer, V., Lott, C., Eickert, G., Fabricius, K.E., De Beer, D., 2007. In situ applications of a new diver-operated motorized microsensor profiler. Environ. Sci. Technol. 41, 6210-6215. 


\section{Figure Captions}

519

520 Fig. 1. Map of the Frasassi cave system, showing sampling locations. Base map after Mariani et

521 al. (2007). No technical caving is required to access sites CS and VC.

522

523 Fig. 2. (A) Conductivity versus $\mathrm{H}_{2} \mathrm{~S}_{\mathrm{T}}$ for Frasassi springs and streams measured from 2007 to 524 2010. (B) Measured $\mathrm{H}_{2} \mathrm{~S}(g)$ degassing rates versus surface flow velocities. At the times of 525 measurement, $\mathrm{H}_{2} \mathrm{~S}_{\mathrm{T}}$ concentrations at site PC were between 450-560 $\mu \mathrm{M}$ and between 100-190 $526 \mu \mathrm{M}$ at sites $\mathrm{GB}$ and $\mathrm{RS}$.

527

528 Fig. 3. Microsensor profiles from Frasassi stream biofilms for a site where $\mathrm{O}_{2}, \mathrm{H}_{2} \mathrm{~S}_{\mathrm{T}}$, and $\mathrm{pH}$ data 529 were all available (A). Panel (B) shows a pH profile (open circles) measured to the sediment530 rock interface at the same location, which resulted in the microsensor breaking. A second $\mathrm{pH}$ 531 profile from the same site is also shown ( $\times$ symbols $)$.

532

533 Fig. 4. Comparison of modeled versus measured changes in $\mathrm{H}_{2} \mathrm{~S}_{\mathrm{T}}$ for the $\mathrm{PC}$ stream at three 534 different times of the year. Circles are measured $\mathrm{H}_{2} \mathrm{~S}_{\mathrm{T}}$ values and lines are model output. The 535 solid curve was modeled using the average microbial oxidation rate $\left(0.49 \mu \mathrm{mol} \mathrm{m} \mathrm{s}^{-1}\right)$, and 536 dashed lines are with the minimum and maximum measured rates (Table 1). Insets show 537 modeled versus measured changes in $\mathrm{pH}$ due to $\mathrm{H}_{2} \mathrm{~S}(g)$ and $\mathrm{CO}_{2}(g)$ degassing.

539 Fig. 5. Mass loss from replicate limestone tablets installed above and below the water table at 540 site RS over a 5-year period (Galdenzi et al., 1997). For comparison, the range of values 
541 determined at the same site for submerged tablets in a later study (Galdenzi, 2012) are also

542 shown (gray bar, $\mathrm{n}=17$ ), including two extreme values (arrow). Subaerial dissolution was not

543 measured in this later study (Galdenzi, 2012).

544

545 Fig. 6. Conceptual framework for predicting when and where subaerial corrosion is expected as 546 the dominant mechanism for speleogenesis in sulfidic caves. Boxes represent the range of $\mathrm{H}_{2} \mathrm{~S}_{\mathrm{T}}$ 547 and flow velocity for sulfidic waters reported this study and for previously studied sulfidic cave 548 systems.

549

550

551

552

553 
554 Table 1. Areal rates of $\mathrm{H}_{2} \mathrm{~S}_{\mathrm{T}}$ loss from cave streams.

\begin{tabular}{|c|c|c|c|}
\hline $\begin{array}{l}\text { water } \\
\text { type }\end{array}$ & site & $\begin{array}{l}\text { range of values } \\
\left(\mu \mathrm{mol} \mathrm{m} \mathrm{m}^{-1}\right)\end{array}$ & $\mathrm{n}$ \\
\hline \multicolumn{4}{|c|}{$\mathrm{H}_{2} \mathrm{~S}(g)$ degassing } \\
\hline 1 & $\mathrm{PC}$ & $0.9-80$ & 31 \\
\hline 2 & $\mathrm{RS}$ & $1.4-7.4$ & 6 \\
\hline 2 & GB & $3.0-4.0$ & 19 \\
\hline \multicolumn{4}{|c|}{ Microbial sulfide oxidation } \\
\hline 2 & GS & $0.45-0.73$ & $2^{*}$ \\
\hline 2 & $\mathrm{CS}$ & $0.15-2.01$ & $5^{*}$ \\
\hline 2 & $\mathrm{VC}$ & $0.08-0.34$ & $8^{*}$ \\
\hline \multicolumn{4}{|c|}{ Abiotic sulfide oxidation $^{\dagger}$} \\
\hline 1 and 2 & & $4.3 \cdot 10^{-3}-3.9 \cdot 10^{-5}$ & \\
\hline
\end{tabular}

*Each measurement consists of three separate microsensor profiles from $1 \mathrm{~cm}^{2}$ of biofilm

${ }^{\dagger}$ calculated by multiplying volumetric rates of abiotic oxidation by stream depth in the model. Range of values for all streams and stream locations is given.

555

556 


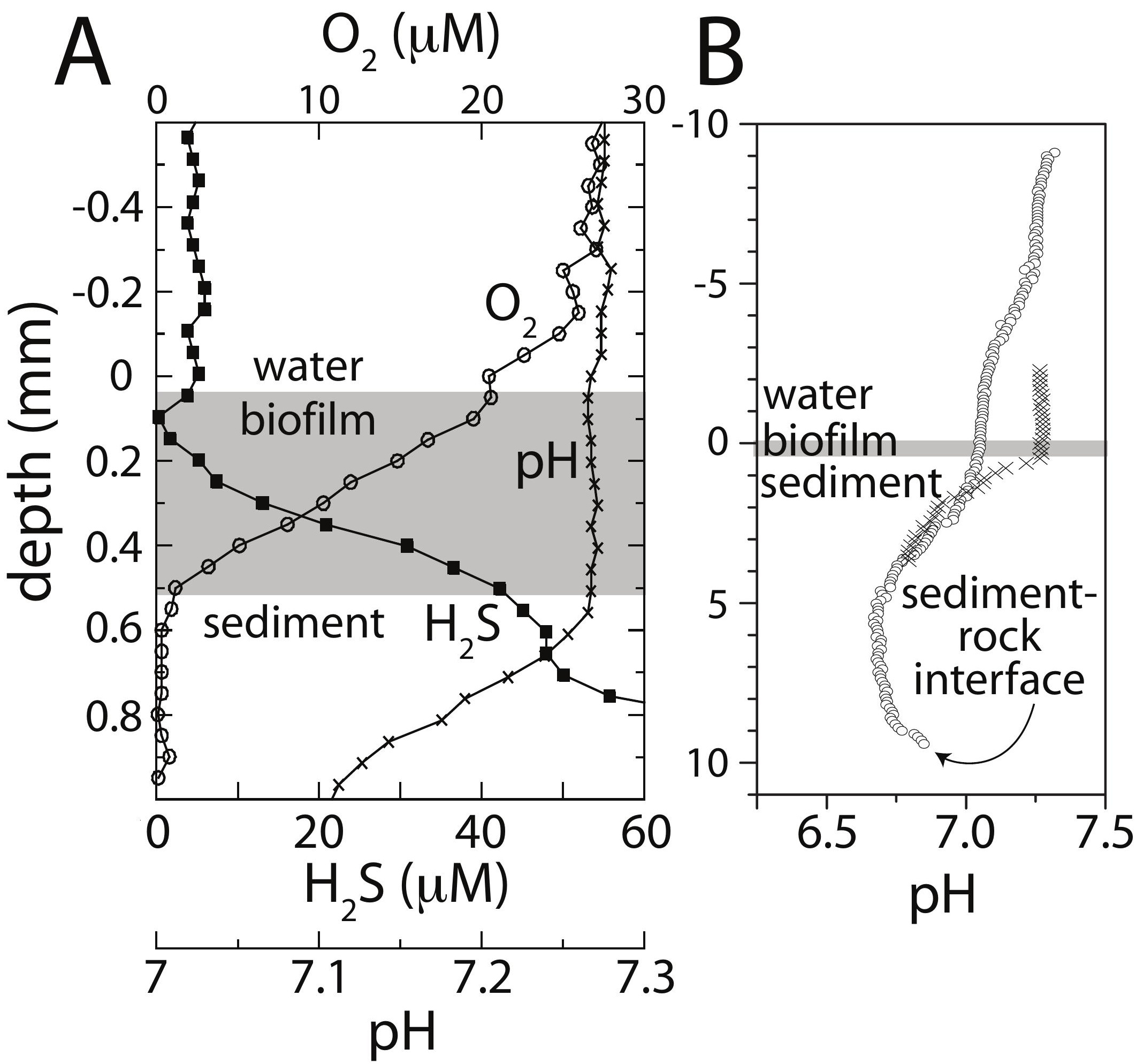




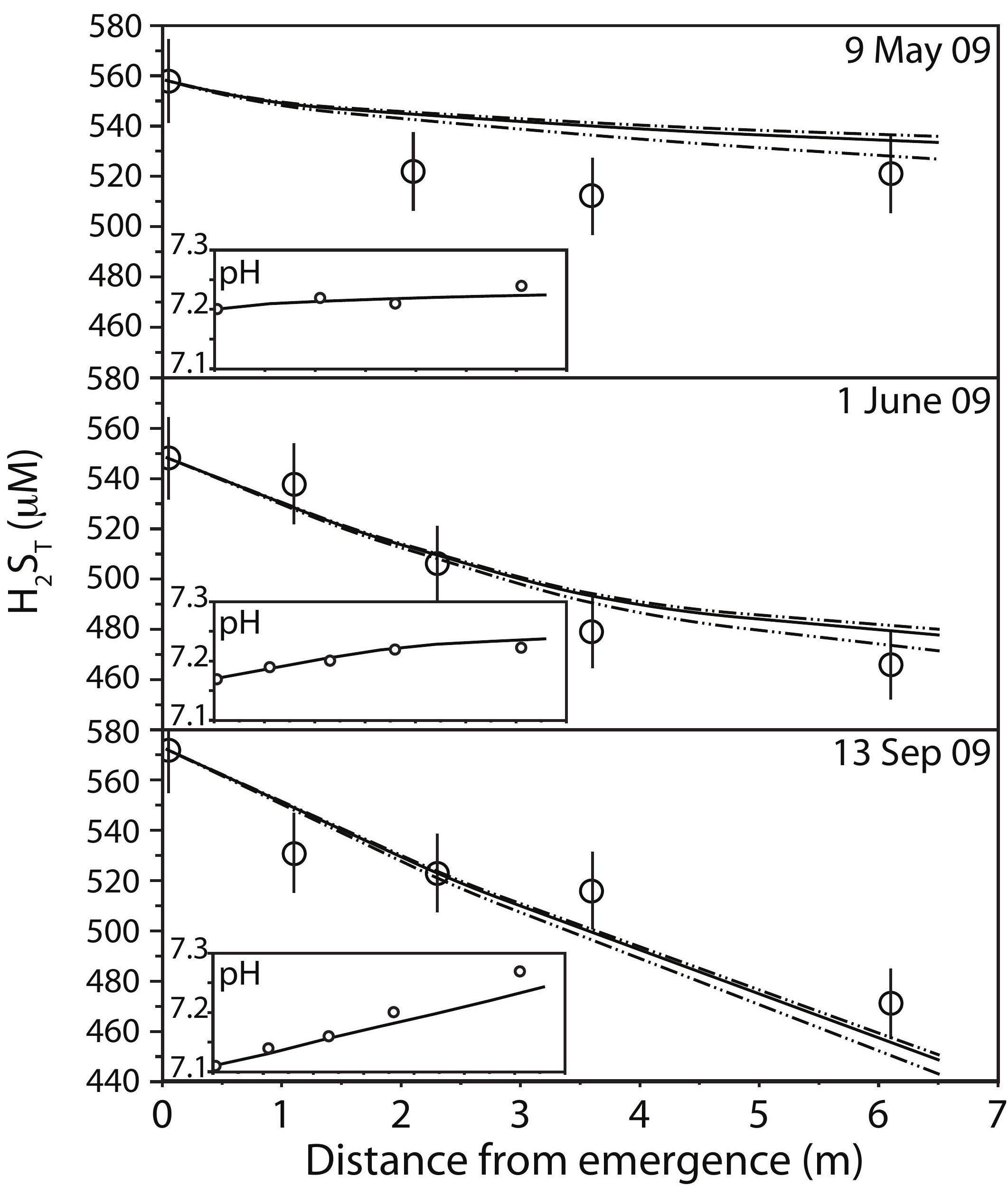




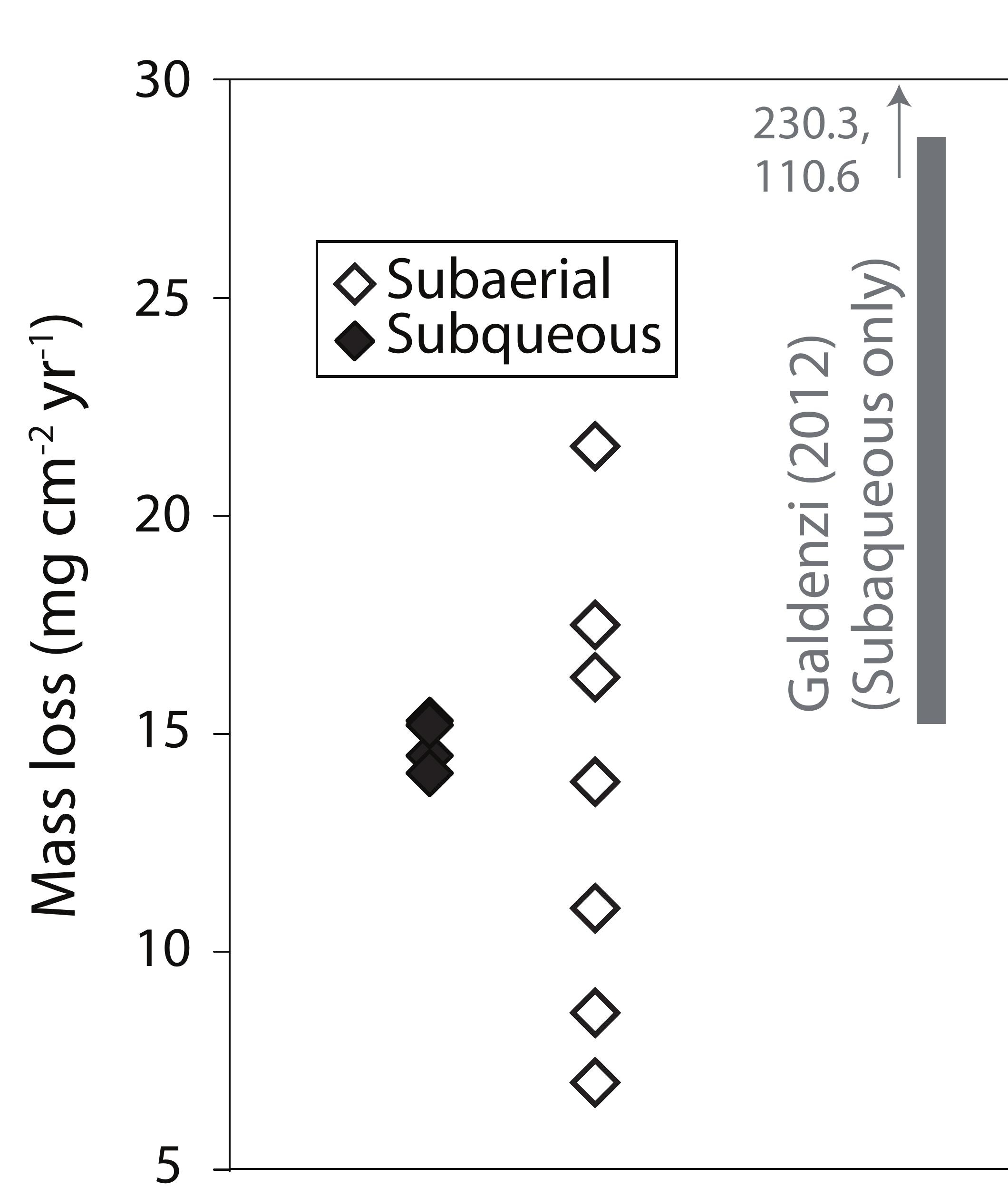

Figure 5

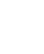

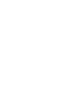

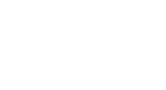




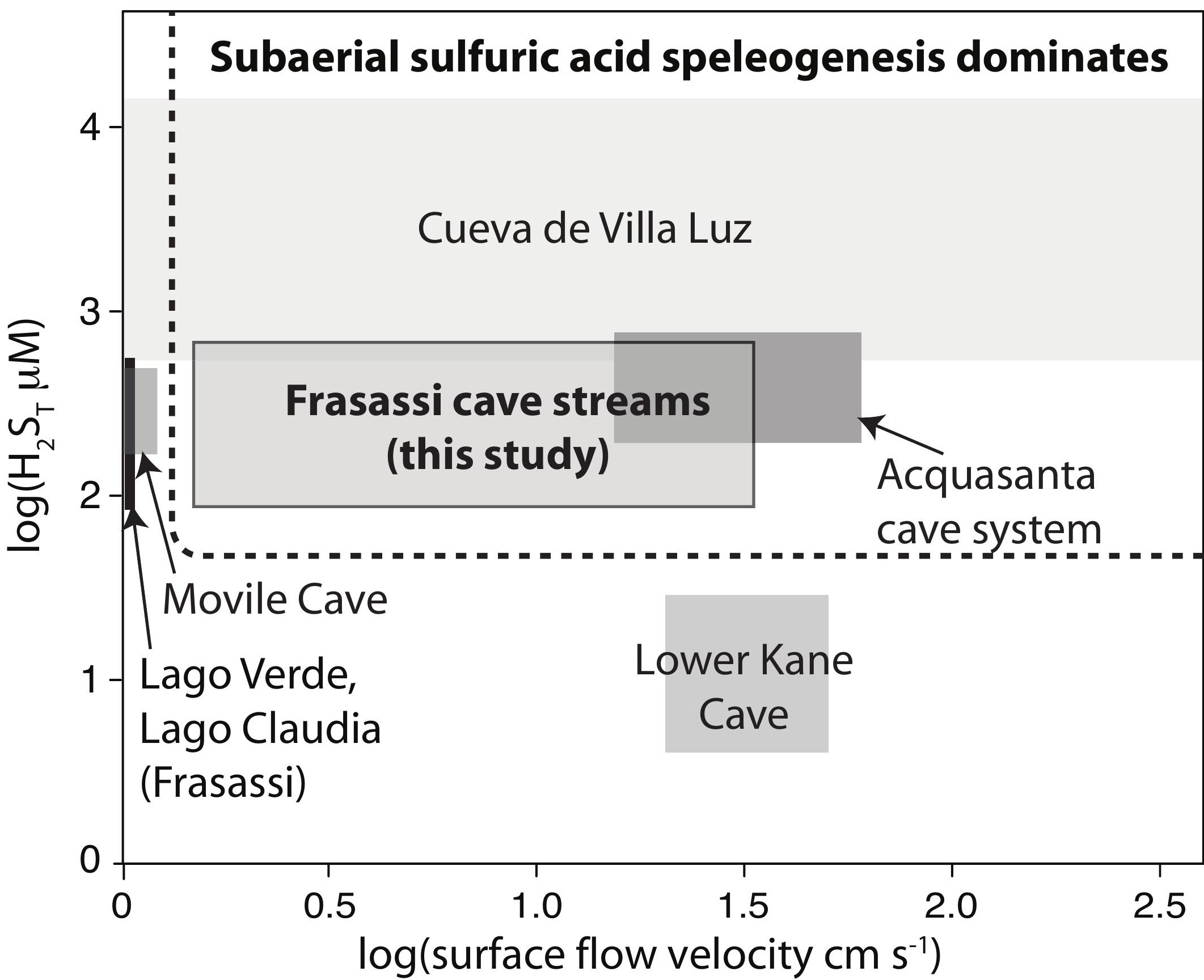

